\title{
KEBUTUHAN GURU PENDIDIKAN AGAMA ISLAM DI SEKOLAH
}

\section{THE NECESSITY OF THE ISLAM EDUCATION (PAI) TEACHER AT SCHOOLS}

\author{
Suprapto \\ Pusat Penelitian dan Pengembangan Kementerian Agama RI. \\ Jl. M.H. Thamrin No. 6, Jakarta Pusat \\ email: supraptolitbang@gmail.com
}

Naskah Diterima: 28 Mei 2018; Direvisi: 9 Agustus 2018; Disetujui: 28 Agustus 2018

\begin{abstract}
Islam Education (PAI) in Nusa Tenggara Barat (NTB) Province is currently not comparable with the number of students and teachers because the impact of moratorium policy, the teachers are retiring, and unscattered number of the PAI teacher. This research used qualitative method. Data collection was conducted through observation, questionnaire, interview, and documentary. Data processing method was editing, coding, tabulating, and interpretation through qualitative and descriptive analysis. Research found that: 1) The shortage of the PAI teachers in NTB, for level SD (Elementary School), SMP (Junior High School), SMA (Senior High School), and SMK (Vocational High School); 2) The Ministry of Religious Affairs-District/City is facing the problem to organize the PAI teacher at schools, due to the recruitment and payroll system of the Education Board (Dinas Pendidikan); 3) The deployment of the PAI teacher has not followed the system of surplus and shortage analysis, based on education unit within the number of study groups; 4) The PAI teacher's supervision at schools through Teachers Working Group (Kelompok Kerja Guru, KKG) and Lesson-Teacher Meeting (Musyawarah Guru Mata Pelajaran, MGMP). This research recommends that: 1) The demand of the PAI teacher at schools can be fulfilled by recruiting temporary teacher (guru honorer), done by schools and Education Board, by giving additional teaching duties for the PAI teacher who has not achieved minimum 24 hours; 2) The PAI teacher's recruitment, deployment and supervision have to be fully authorized by The Ministry of Religious Affairs; 3) The surplus and shortage analysis of the PAI teacher is needed in Level Education Board (Dinas Pendidikan), The Ministry of Religious Affairs-District/City, and Education unit, and 4) The Ministry of Religious Affairs through Directorate of Islam Education (Direktorat Pendidikan Agama Islam) should allocate operational budget for proper KKG/MGMP actitivities of PAI.
\end{abstract}

Keywords: Necessity; Procurement; The PAI teacher; Supervision

\begin{abstract}
Abstrak
Penyelengaraan Pendidikan Agama Islam (PAI) di Provinsi Nusa Tenggara Barat saat ini belum optimal karena tidak sebandingnya jumlah guru dengan siswa sebagai akibat adanya kebijakan moratorium, ada yang pensiun dan tidak meratanya sebaran guru PAI. Penelitian ini menggunakan metode kualitatif. Pengumpulan data melalui teknik observasi, angket, wawancara dan dokumentasi. Teknik pengolahan melalui tahapan editing, coding, tabulating dan interpretation data dengan menggunakan analisis deskriptif kualitatif. Temuan penelitian: 1) Jumlah guru PAI pada jenjang SD, SMP, SMA dan SMK masih kurang; 2) Kementerian Agama mengalami kesulitan mengkoordinasikan guru PAI di sekolah karena pengangkatan, penempatan dan penggajian oleh Dinas Pendidikan; 3) Penempatan guru PAI belum berdasarkan kepada sistem analisis kelebihan dan kekurangan guru berdasarkan satuan pendidikan sesuai jumlah rombongan belajar; 4) Pembinaan guru PAI di sekolah melalui Kelompok Kerja Guru (KKG) dan Musyawarah Guru Mata Pelajaran (MGMP). Penelitian ini merekomendasikan: 1) Pemenuhan guru PAI di sekolah dapat dilakukan melalui pengangkatan guru honorer atau dengan memberikan tugas tambahan mengajar yang belum memenuhi jumlah minimal 24 jam; 2) Pengangkatan, penempatan dan pembinaan guru PAI seharusnya menjadi kewenangan penuh Kementerian Agama; 3) Perlu sistem analisis kelebihan dan kekurangan dalam penempatan guru PAI pada satuan pendidikan dan 4) Kementerian Agama perlu menganggarkan dana operasional KKG/MGMP PAI yang memadai.
\end{abstract}

Kata kunci: Guru PAI; Need assesment; Pengadaan; Pembinaan 


\section{PENDAHULUAN}

Pendidikan agama

merupakan pendidikan yang memberikan pengetahuan, keterampilan, dan membentuk sikap peserta didik dalam mengamalkan ajaran agama pada semua jalur, jenjang, dan jenis pendidikan. Secara umum pendidikan agama berfungsi untuk membentuk manusia Indonesia yang beriman dan bertakwa kepada Tuhan Yang Maha Esa serta berakhlak mulia dan mampu menjaga kerukunan hubungan antar umat beragama (Penjelasan Pasal 37 Undangundang Nomor 20 Tahun 2003 tentang Sistem Pendidikan Nasional). Seiring dengan hal tersebut pendidikan agama Islam bertujuan untuk meningkatkan keimanan, pemahaman, penghayatan dan pengamalan peserta didik tentang agama Islam, sehingga menjadi manusia muslim yang beriman dan bertaqwa kepada Allah swt serta berakhlak mulia dalam kehidupan pribadi, bermasyarakat berbangsa dan bernegara.

Permasalahannya, penyelenggaraan pendidikan agama Islam di sekolah belum optimal karena kurangnya jumlah guru pendidikan agama Islam. Jumlah guru pendidikan agama Islam di provinsi Nusa tenggara barat saat ini tidak sebanding dengan jumlah siswa muslim sebagai akibat kebijakan moratorium pengangkatan guru pendidikan agama Islam PNS, ada yang pensiun dan tidak meratanya sebaran guru pendidikan agama Islam. ${ }^{1}$ Bahkan Menteri Agama mengatakan bahwa Indonesia kekurangan guru agama dan meminta rekrutmen guru agama dilakukan oleh Kementerian Agama. $^{2}$ Permintaan Menteri Agama yang juga dikuatkan oleh Sekretaris Jenderal Kemenag ini terkait keluhan kekurangan guru pendidikan agama di setiap daerah. Kekurangan guru agama tersebut disebabkan beberapa faktor: 1) sejak satu dekade yang lalu, pemerintah melakukan moratorium pengangkatan PNS 2) Adanya guru agama yang masuk masa purnabakti 3) sebaran guru agama yang tidak merata. Hal ini mengakibatkan proses pembelajaran Pendidikan Agama Islam di sekolah dilakukan

${ }^{1}$ H. Jaelani, M.Pd., Kepala Bidang Pendidikan Agama Islam Provinsi Nusa Tenggara Barat, Wawancara, 19 Mei 2017 (Pinmas)

${ }^{2}$ Berita Kemenag.go.id 11/11/2016 Makassar oleh guru yang bukan bidangnya dan hal ini dihawatirkan akan mengakibatkan menurunnya kualitas PAI.

Berdasarkan data di Kementerian Agama, saat ini terjadi kekurangan guru Pendidikan Agama Islam (PAI) sebanyak 37.600 orang. Hal ini apabila diambil rasio jumlah guru PAI hanya satu orang persekolah. Dirjen Pendidikan Islam Kementerian Agama Komaruddin Amin, mengatakan akar permasalahan kurangnya guru PAI ini dikarenakan rekrutmen guru PAI di sekolah umum statusnya adalah PNS daerah dan pada sejumlah daerah, keberadaan guru PAI masih belum menjadi prioritas. Jumlah alokasi guru PAI yang baru, tidak sebanding dengan jumlah yang pensiun. Kamaruddin juga menjelaskan mata pelajaran PAI tidak bisa dipandang sebelah mata. Selain permasalahan kekurangan guru PAI di sekolah, juga dihadapkan persoalan lain yaitu tidak meratanya penyebaran dan lemahnya pembinaan guru PAI. Guru sering menjadi pihak yang dipersalahkan ketika pendidikan menunjukkan hasil yang mengecewakan. Karena itu, perlu diadakan berbagai upaya serius dalam penyebaran guru PAI pada satuan pendidikan dan upaya pembinaan untuk peningkatkan professional guru PAI misalnya melalui kegiatan KKG/MGMP. ${ }^{3}$

Hasil penelitian Puslitbang Pendidikan Agama dan Keagamaan tahun 2014 tentang efektifitas MGMP dalam peningkatan Profesionalisme guru, $85 \%$ responden menyatakan MGMP sangat efektif sebagai wadah dalam meningkatkan profesionalisme, bisa meningkatkan kemampuan akademik, meningkatkan kompetensi dalam mengajar, dan menumbuhkan semangat guru dalam proses belajar mengajar karena melalui MGMP, guru bisa mendapatkan pengalaman dan pembelajaran dari para anggotanya ${ }^{4}$.

Permasalahannya bagaimana sebaran dan rasio guru dengan siswa? dan bagaimana pola perekrutan, penempatan dan pembinaan guru

${ }^{3}$ H.M. Hasbullah. 2015. Kebijakan Pendidikan Dalam Perspektif Teori, Aplikasi, dan Kondisi Obyektif Pendidikan di Indonesia, cet.1 Rajawali Pers, hal. 165

${ }^{4}$ Lisa'diyah Ma'rifataini. 2014. Jurnal Edukasi, Jurnal Penelitian Pendidikan Agama dan Keagamaan Volume 12, Nomor 1 Januari-April, Puslitbang Pendidikan Agama dan Keagamaan, hal. 75 
PAI pada satuan pendidikan? Metode penelitian ini adalah kualitatif yang didukung oleh data-data kuantitatif. Untuk mengumpulkan data dalam penelitian ini digunakan teknik observasi, angket, wawancara dan dokumenter. Adapun teknik pengolahan data yang digunakan adalah editing, koding, tabulating dan interpretasi data dengan menggunakan analisis deskriptif kualitatif. Lokus penelitian ini di propinsi Nusa tenggara Barat dengan pertimbangan: 1) representatif mewakili zona di Indonesia serta karena keragaman, minoritas dan mayoritas pemeluk agamanya; dan 2) penyebaran rasio guru PAI dengan siswa dengan kategori tinggi, sedang dan rendah.

\section{Kajian Literatur}

\section{Needs Assessment}

Konsep pemenuhan kebutuhan dalam studi ini digunakan konsep need assessment. Assesment didefinisikan sebagai proses untuk mengidentifikasi jarak/gap antara yang dicitacitakan dengan kenyataan yang ada. Roger Kaufman dkk, menjelaskan bahwa assessment ini dikaitkan dengan istilah needs yang berarti kebutuhan. Menurut mereka, needs assessment merupakan suatu proses yang digunakan untuk mengidentifikasi gap antara realitas yang ada dengan sesuatu yang diidealkan/dicita-citakan. Kemudian menempatkan gap tersebut ke dalam skala prioritas yang akhirnya memilih salah satunya untuk dipenuhi. ${ }^{5}$ Berdasarkan rujukan tersebut maka yang dimaksud dengan pemenuhan kebutuhan dalam studi ini adalah penelusuran terhadap tingkat pemenuhan guru pendidikan agama Islam di Sekolah pada seluruh jenjang SD, SMP dan SMA/SMK yang mencakup: penerimaan dan penarikan guru, dan pembinaan guru pendidikan agama.

\section{Guru Pendidikan Agama Islam}

Dalam Undang-undang Nomor 14 Tahun 2005 tentang guru dan dosen pada Bab I Pasal 1 ayat 1 disebutkan bahwa guru adalah pendidik professional dengan tugas utama mendidik, mengajar, membimbing,

${ }^{5}$ Roger Kaufman, Alicia M. Rojas \& Hanna Mayer. 1993. Needs Assessment A User's Guide, Education Technology Publications, Englewood Cliffs, New Jersey, hal.3 mengarahkan, melatih dan mengevaluasi peserta didik pada pendidikan anak usia dini jalur pendidikan formal, pendidikan dasar dan pendidikan menengah. Oleh karena itu guru merupakan salah satu unsur yang harus berperan dan menempatkan diri sebagai tenaga professional. Dalam arti khusus dapat dikatakan bahwa pada setiap diri guru terletak tanggungjawab untuk membawa para siswanya pada suatu kedewasaan atau taraf kematangan tertentu.

Organisasi profesional guru sedunia mengungkapkan bahwa peranan guru di sekolah tidak hanya sebagai transmitter ide, tetapi juga berperan sebagai transformer dan katalisator nilai dan sikap. ${ }^{6}$ Sebelum tampil didepan kelas mengelola interaksi belajar mengajar, terlebih dahulu guru harus menguasai bahan apa yang harus dikontakkan dan sekaligus bahan-bahan apa yang dapat mendukung jalannya proses belajar mengajar. Dengan modal penguasaan bahan ajar, maka guru akan dapat menyampaikan materi pelajaran secara sistematis dan dinamis. Karena alasan inilah maka bagi seorang guru diwajibkan untuk memenuhi syarat bukan saja sebagai orang yang pandai tapi juga orang yang berbudi, orang yang beriman yang perbuatannya sendiri dapat memberikan pengaruh pada jiwa anak didiknya. Bukan hanya apa yang diajarkannya saja yang penting; tetapi apa yang ia lakukan, cara dia membawa diri, sikapnya di dalam dan di luar kelas, semuanya diharapkan sesuai dengan cita-cita yang tanpa keraguan sedikitpun diterima oleh muridnya. ${ }^{7}$

Dalam Undang-undang No.14 tahun 2005 tentang guru dan dosen pada Bab IV Pasal 8, 9 dan 10 ditegaskan beberapa aspek tentang guru. Di antaranya adalah bahwa guru wajib memiliki kualifikasi akademik, kompetensi, sertifikat pendidik, sehat jasmani dan rohani, serta memiliki kemampuan untuk mewujudkan tujuan pendidikan nasional.

${ }^{6}$ Sudirman AM. 1994. Interaksi dan Motivasi Belajar Mengajar, Pedoman Guru dan Calon Guru. Jakarta: PT Raja Grafindo Persada: Cetakan Kelima, hal.142.

${ }^{7}$ Syed Sajjad Husain, dkk, Menyongsong Keruntuhan Pendidikan Islam, diterjemahkan oleh Rahmani Astuti dari judul asli Crisis Muslim Education, (Bandung: Gema Risalah Press, Cetakan Kelima, 1994) hal. 158 
Kompetensi yang dimaksud dalam hal tersebut meliputi kompetensi pedagogic, kompetensi kepribadian, kompetensi sosial, dan kompetensi professional yang diperoleh melalui pendidikan profesi. Hal ini sejalan dengan UU. No. 20 Tahun 2003 tentang Sisdiknas pada Pasal 12 ayat 1.a mengamanatkan bahwa setiap peserta didik pada setiap satuan pendidikan berhak mendapatkan pendidikan agama sesuai dengan agama yang dianutnya dan diajarkan oleh pendidikan yang seagama. Setiap tenaga kependidikan, termasuk di dalamnya guru agama, berkewajiban untuk melaksanakan tugas dengan penuh tanggungjawab dan pengabdian, meningkatkan kemampuan professional sesuai dengan tuntutan perkembangan ilmu pengetahuan dan teknologi serta pembangunan bangsa. Berdasarkan rujukan tersebut yang dimaksud dengan Guru
Pendidikan Agama dalam studi ini adalah guru pendidikan agama Islam yang bertugas di SMP Negeri dan Swasta baik yang diangkat oleh pemerintah maupun yayasan/sekolah.

\section{METODOLOGI PENELITIAN}

Berdasarkan konsep needs assessment di atas yang dimaksud dengan analisis kebutuhan guru dalam studi ini adalah suatu proses penghitungan terhadap jumlah guru pendidikan agama Islam di SD, SMP dan SMSA/SMK yang tersedia dengan jumlah guru agama yang dibutuhkan. Dengan demikian akan diketahui jumlah guru pendidikan agama yang ideal berdasarkan rasio jumlah guru pendidikan agama dengan rombongan belajar.

Analisis kebutuhan guru dengan menggunakan formula sebagai berikut.

\section{Jumlah Jam Pelajaran per Minggu x Jumlah Rombongan Belajar}

\section{Jumlah Jam Wajib Mengajar}

Sumber: Pedoman Umum Pengelolaan MAN Model, PPA Consultans in Association with IAIN Walisongo, IAIN Sunan Kalijaga dan Cambrridge Education Consultans Ltd. 2000

Misalnya: Jumlah jam mengajar guru pendidikan agama: 2jam/minggu; Jumlah rombongan belajar: kelas $1=$ 8rombongan belajar, kelas $2=8$ rombongan belajar dan kelas $3=$ 8rombongan belajar, dan Jumlah wajib mengajar guru: 24 jam/minggu. Maka kebutuhan guru pendidikan agama pada lembaga yang bersangkutan:

$$
\frac{(2 \times 8)+(2 \times 8)+(2 \times 8)}{24}=\frac{16+16+16}{24}=\frac{48}{24}=2 \text { orang }
$$

Apabila di lembaga yang bersangkutan hanya memiliki 1 orang guru agama maka lembaga ini masih kekurangan lorang guru pendidikan agama, atau dengan kata lain lembaga yang bersangkutan harus mengadakan/mengangkat 1 orang guru agama lagi.

\section{Pengertian, Fungsi dan Tujuan KKG dan MGMP}

KKG ataupun MGMP adalah suatu forum profesionalisme guru yang berada pada suatu wilayah kabupaten/kota/kecamatan/ sanggar/gugus sekolah, yang ruang lingkupnya meliputi guru mata pelajaran, baik yang berstatus PNS maupun Swasta. Prinsip kerjanya adalah cerminan kegiatan dari, oleh, dan untuk guru dari semua sekolah baik negeri maupun swasta. Atas dasar ini, maka MGMP merupakan organisasi non-struktural yang bersifat mandiri, berasaskan kekeluargaan, dan tidak mempunyai hubungan hierarkis dengan lembaga lain. ${ }^{8}$

Fungsi KKG/MGMP PAI adalah: 1) Sebagai forum komunikasi antar Guru Pendidikan Agama Islam (GPAI) dalam meningkatkan kemampuan profesional dan fungsional, 2) Sebagai forum konsultasi yang berkaitan dengan kegiatan pembelajaran, khususnya yang menyangkut materi pembelajaran, metode pembelajaran, evaluasi hasil pembelajaran, dan sarana penunjang, 3)

${ }^{8}$ Arief Ahmad, M.SP, M.Pd. 2004. Memberdayakan MGMP Sebuah Keniscayan (www.geogle Ariefmangkoesapoetro.com) 
Sebagai forum penyebarluasan informasi tentang kebijakan yang berkaitan dengan usaha-usaha pembaharuan dalam bidang pendidikan.

Sedangkan tujuan KKG/MGMP PAI adalah: 1) Meningkatkan ukhuwah Islamiyah dan tanggung jawab sebagai guru mata pelajaran Pendidikan Agama Islam yang bertujuan menanamkan keimanan dan ketaqwaan terhadap Allah swt.; 2) Meningkatkan kompetensi Guru Pendidikan Agama Islam (GPAI) dalam melaksanakan kegiatan pembelajaran, sehingga dapat menunjang usaha peningkatan pemerataan mutu Pendidikan Agama Islam; 3) Meningkatkan kemampuan profesionalisme berkarya dan berprestasi dalam pelaksanaan sertifikasi dan angka kredit bagi jabatan fungsional GPAI; 4) Menumbuhkan kegairahan GPAI untuk meningkatkan kemampuan dan keterampilan dalam mempersiapkan, melaksanakan, dan mengevaluasi program pembelajaran PAI; 5) Menampung segala permasalahan yang dihadapi GPAI dalam melaksanakan tugas sehari-hari dan bertukar pikiran serta mencari solusi sesuai dengan karakteristik PAI, GPAI, sekolah, dan lingkungan; 6) Membantu GPAI dalam upaya memenuhi kebutuhannya yang berkaitan dengan kegiatan pembelajaran PAI; 7) Membantu GPAI dalam memperoleh informasi teknis edukatif yang berkaitan dengan kegiatan PAI dan integrasi dengan mata pelajaran lain; 8) Membantu GPAI bekerjasama dalam meningkatkan kegiatan- kegiatan intra dan ekstra kurikulum PAI; 9) Membantu GPAI dalam memperoleh kesempatan peningkatan pendidikan akademis untuk memenuhi tuntutan UU Nomor 14 Tahun 2005 tentang Guru dan Dosen, sehingga dapat memperoleh kualifikasi dan sertifikasi sesuai yang diharapkan DAN 90 Memperluas wawasan dan saling tukar informasi dan pengalaman dalam rangka mengikuti perkembangan Iptek dan pengembangan metode ataupun tenik pembelajaran PAI.

\section{HASIL PENELITIAN}

\section{Jumlah Satuan Pendidikan Dasar dan Menengah di NTB}

Jumlah sekolah pendidikan dasar dan menengah di 10 Kabupaten/Kota Provinsi Nusa Tenggara Barat sebanyak 9.622 satuan pendidikan terdiri dari 4.015 SD/MI, 1.741 SMP/MTs, 867 SMA/MA dan 299 SMK. Secara rinci dapat dikemukakan bahwa SD negeri berjumlah 3.030 buah dan swasta 985 buah, SMP Negeri berjumlah 626 buah dan swasta 1.115 buah, SMA/MA negeri berjumlah 169 buah dan swasta 698 buah dan SMK Negeri berjumlah 89 buah dan swasta 210 buah. Dari jumlah sekolah ini tergambar bahwa SD/MI negeri lebih banyak dibandingkan swasta sebaliknya SMP/MTs, SMA/MA dan SMK negri lebih sedikit dibandingkan swasta. Jumlah sekolah di 10 kabupaten/kota di Provinsi Nusa Tenggara Barat dapat dilihat dalam table berikut ini.

Tabel 1. Jumlah satuan pendidikan (sekolah) di Provinsi Nusa Tenggara Barat tahun 2017

\begin{tabular}{|c|c|c|c|c|c|c|c|c|c|c|c|c|c|c|}
\hline \multirow{2}{*}{ No } & \multirow{2}{*}{$\begin{array}{c}\text { Kabupaten/ } \\
\text { Kota }\end{array}$} & \multicolumn{3}{|c|}{ SD/MI } & \multicolumn{3}{|c|}{ SMP/MTs } & \multicolumn{3}{|c|}{ SMA/MA } & \multicolumn{3}{|c|}{ SMK } & \multirow[t]{2}{*}{$\sum$} \\
\hline & & $\mathrm{N}$ & $\mathrm{S}$ & $\sum$ & $\mathrm{N}$ & $\mathrm{S}$ & $\sum$ & $\mathrm{N}$ & $\mathrm{S}$ & $\sum$ & $\mathrm{N}$ & $S$ & $\sum$ & \\
\hline 1 & Lobar & 342 & 110 & 452 & 57 & 136 & 193 & 16 & 86 & 102 & 14 & 27 & 41 & 788 \\
\hline 2 & Loteng & 579 & 315 & 494 & 95 & 353 & 448 & 21 & 221 & 242 & 11 & 47 & 58 & 1542 \\
\hline 3 & Lotim & 661 & 290 & 951 & 106 & 349 & 455 & 25 & 192 & 217 & 10 & 71 & 81 & 1704 \\
\hline 4 & Sumbawa & 365 & 35 & 400 & 96 & 39 & 139 & 22 & 24 & 46 & 10 & 7 & 17 & 598 \\
\hline 5 & Dompu & 213 & 53 & 266 & 50 & 50 & 100 & 18 & 30 & 48 & 9 & 12 & 21 & 435 \\
\hline 6 & Bima & 416 & 68 & 484 & 115 & 73 & 188 & 35 & 58 & 93 & 10 & 15 & 25 & 790 \\
\hline 7 & $\begin{array}{l}\text { Sumbawa } \\
\text { Barat }\end{array}$ & 89 & 15 & 104 & 30 & 14 & 44 & 8 & 9 & 17 & 5 & 3 & 8 & 173 \\
\hline 8 & LombokUtara & 143 & 43 & 186 & 33 & 49 & 82 & 7 & 27 & 34 & 5 & 7 & 12 & 314 \\
\hline 9 & KotaMataram & 149 & 41 & 190 & 27 & 36 & 63 & 10 & 30 & 40 & 10 & 13 & 23 & 316 \\
\hline 10 & Kota Bima & 73 & 15 & 88 & 17 & 16 & 33 & 7 & 21 & 28 & 5 & 8 & 13 & 162 \\
\hline & Jumlah & 3030 & 985 & 4015 & 626 & 1115 & 1741 & 169 & 698 & 867 & 89 & 210 & 299 & 9622 \\
\hline
\end{tabular}

Sumber: Data satuan pendidikan (sekolah), Dinas Pendidikan dan Kebudayaan Propinsi Nusa Tenggara Barat, tahun 2017 


\section{Keadaan Lembaga, Guru, Rombongan Belajar dan Siswa SD, SMP, SMA dan SMK $^{9}$}

Jumlah satuan pendidikan pada tingkat dasar dan menengah di 10 (sepuluh) Kabupaten/Kota provinsi Nusa Tenggara Barat. Pada tingkat pendidikan dasar, SD berjumlah 3.244 sekolah (3.077 negeri dan 167 swasta) dan SMP berjumlah 969 sekolah (700 negeri dan 269 swasta). Sedangkan untuk tingkat pendidikan menengah, SMA berjumlah 359 sekolah (179 negeri dan 167 swasta) dan SMK berjumlah 318 sekolah (110 negeri dan 208 swasta). Dari jumlah sekolah ini terlihat bahwa sekolah negeri pada jenjang SD dan SMP lebih banyak dibandingkan swasta. Hal ini berbeda dengan jumlah sekolah pada pendidikan menengah menunjukkan SMA negeri dan swasta hampir sebanding hanya selisih sat buah. Sedangkan untuk jenjang SMK swasta lebih banyak dibandingkan negeri setengah lebih sedikit SMK negeri dibandingkan swasta. Bila dilihat dari jumlah sekolah per kabupaten/kota menunjukkan bahwa jumlah SD terbanyak pada Kabupaten Lombok Timur (727 SD) diikuti Lombok Tengah (606 SD) dan Lombok Barat (367 SD). Pada tingkat SMP, terbanyak pada Lombok Timur (195 SMP), Lombok Tengah (181 SMP) dan Bima (144 SMP). Untuk tingkat SMA, terbanyak pada kabupaten Bima (65 SMA), Lombok Tengah (58 SMA) dan Lombok Timur (56 SMA). Sedangkan pada tingkat SMK, terbanyak pada kabupaten Lombok Timur (66 SMK) diikuti Lombok Timur (56 SMK) dan Lombok Barat (47 SMK).

Jumlah guru PAI SD, SMP, SMA dan SMK negeri dan swasta di 10 Kabupaten/ Kota provinsi Nusa Tenggara Barat. Pada tingkat pendidikan dasar, Jumlah guru PAI jenjang SD seluruhnya berjumlah 2.897 orang (2.826 negeri dan 71 swasta) dan jumlah guru PAI jenjang SMP berjumlah 731 orang (600 negeri dan 71 swasta). Selanjutnya pada tingkatpendidikan menengah, jumlah guru PAI SMA berjumlah 342 orang (275 negeri dan 67 swasta) dan jenjang SMK berjumlah 233 orang (163 negeri dan 70 swasta). Data ini

${ }^{9}$ Data Kelembagaan Pendidikan Agama Islam, Bidang Pendidikan Agama Islam, Kantor Wilayah Kementerian Agama Provinsi Nusa Tenggara Barat Tahun 2016/2017. menunjukkan bahwa guru PAI swasta yang perlu diangkat menjadi PNS seluruhnya berjumlah 289 orang yang terdiri 71 orang jenjang SD, 71 orang jenjang SMP, 67 jenjang SMA dan 70 orang SMK.

Jumlah rombongan belajar SD, SMP, SMA dan SMK di 10 (sepuluh) kabupaten Kota provinsi Nusa Tenggara Barat. Pada jenjang SD berjumlah 17.441 rombel (16.978 negeri dan 463 swasta) diikuti jenjang SMP berjumlah 5.799 rombel (5.259 negeri dan 540 swasta), SMA berjumlah 3.044 rombel (2.704 negeri dan 340 swasta) dan SMK berjumlah 1.462 rombel (1.184 negeri dan 278 swasta).

Jumlah siswa muslim di 10 Kabupaten/Kota Provinsi Nusa Tenggara Barat seluruhnya berjumlah 797.129 orang terdiri dari SD sebanyak 431.607 orang (422.207 orang di SD negeri dan 9.400 orang di SD swasta); SMP sebanyak 183.057 orang (169.295 orang di SMP negeri dan 13.762 orang di SMP swasta); SMA sebanyak 132.290 orang (122.039 orang di SMA negeri dan 10.251 orang di SMA swasta) dan SMK sebanyak 49.625 orang (42.774 orang di SMK negeri dan 6.841 orang di SMK swasta).Data ini menggambarkan adanya SMP dan SMK swasta di Kabupaten Lombok Utara tidak ada siswa yang beragama Islam demikian halnya dengan SMK swasta di Kabupaten Sumbawa Barat. Mereka beragama Budha, Hindu, Katolik dan Kristen.

\section{Kebutuhan Riil Guru Pendidikan Agama Islam Negeri Jenjang SD, SMP, SMA dan SMK}

Hasil penghitungan kelebihan dan kekurangan guru PAI yang berstatus negeri pada jenjang SD sesuai kurikulum 2013 di Provinsi Nusa Tenggara Barat terjadi kelebihan guru sebanyak 68 orang. Keadaan ini tidak merata antar Kabupaten/Kota, Kabupaten Lombok Timur masih kekurangan 137 orang guru diikuti oleh Kabupaten Sumbawa 41 orang dan Kota Mataram 20 orang. Sedangkan untuk 7 Kabupaten/Kota lainnya telah cukup memadai. Sementara yang mengalami kelebihan guru pada Lobar (16 orang); Lombok Utara (30 orang); Loteng (6 orang); Sumbawa Barat (15 orang); Dompu (55 orang); Bima (108 orang) dan Kota Bima (36 orang). 
Hasil penghitungan kelebihan dan kekurangan guru PAI yang berstatus negeri pada jenjang SMP sesuai kurikulum 2013 di 10 (sepuluh) Kabupaten/Kota di provinsi Nusa Tenggara Barat telah mencukupi bahkan jumlahnya melebihi 74 orang dengan status non PNS. Namun bila dilihat per kabupaten/Kota maka di Kota Mataram masih mengalami kekurangan 94 orang guru. Persoalannya pendistribusian guru PAI di provinsi ini belum merata.

Hasil penghitungan kelebihan dan kekurangan guru PAI yang berstatus negeri pada jenjang SMA sesuai kurikulum 2013 di 10 (sepuluh) Kabupaten/Kota di provinsi Nusa Tenggara Barat masih kekurangan guru PAI sebanyak 137 orang. Dari jumlah ini tersebar pada Kota Mataram (81 orang), Kabupaten Lombok Timur (22 orang), Lombok Tengah (14 orang), Bima (9 orang), Sumbawa (6 orang), Dompu (6 orang) dan Kota Bima (5 orang). Sedangkan untuk Kabupaten Lombok Barat, Lombok Utara dan Sumbawa barat sudah mencukupi.

Hasil penghitungan kelebihan dan kekurangan guru PAI yang ber-status negeri pada jenjang SMK negeri swasta sesuai kurikulum 2013 di 10 (sepuluh) Kabupaten/Kota di provinsi Nusa Tenggara Barat masih kekurangan guru PAI sebanyak 36 orang. Bila dilihat dari jumlah status kepegawaian PNS masih perlu diangkat 19 guru PAI Kota Mataram, 10 guru PAI di Kabupaten Lombok Barat 10 guru PAI di Kota Bima, 19 guru PAI di Kabupaten Lombok Timur,13 guru PAI di Dompu dan 5 guru PAI di Kota Bima.

Berdasarkan informasi dari Kepala Seksi PAI, Kepala Sekolah SD Negeri 2 Selong, SMP Negeri 4 Praya dan SMA Negeri 1 Kota Mataram bahwa jumlah guru PAI pada tingkat pendidikan dasar dan menengah sudah cukup namun karena penyebarannya tidak merata mengakibatkan adanya beberapa sekolah mengalami kekurangan guru PAI. Disamping itu juga karena meningkatnya jumlah siswa mengakibatkan naiknya jumlah rombongan belajar yang tidak diikuti dengan tambahnya jumlah guru PAI yang ada. Pemecahannya, masing masing sekolah mengangkat guru PAI honorer. Adapun persyaratannya adalah: 1) berlatar belakang $\mathrm{S} 1$ fakultas Tarbiyah atau jurusan PAI; 2) bersangkutan masih bebas tidak memiliki tanggungjawab dengan sekolah lain; 3) memiliki ketarampilan baca tulis al Qur'an dengan baik; 4) bersedia untuk meyelenggarakan kegiatan ekstra kurikuler keagamaan baik untuk siswa maupun guru. ${ }^{10}$ Melalui persyaratan ini diharapkan guru PAI yang besangkutan dapat dimaksimalkan dalam pengembangan penyelenggaraan pendidikan agama Islam di sekolah. Mereka digaji melalui dana BOS. Pengangkatan mereka melalui SK kepala sekolah yang selanjutnya dilaporkan kepada Dinas Pendidikan Kabupaten/Kota. ${ }^{11}$ Disamping itu kurangnya guru PAI di sekolah juga diakibatkan karena pensiun, meninggal dan kebijakan moratorium dari pemerintah.

Dalam pengangkatan guru PAI disekolah Dinas Pendidikan Kabupaten/Kota tidak berkoordinasi dengan Kementerian Agama Kabupaten/Kota. Pengangkatan guru PAI di sekolah menjadi kewenangan atau otoritas penuh pemerintrah daerah. Kondisi ini mengakibatkan guru PAI kurang menghargai Kementerian Agama Propinsi dan Kabupaten/Kota karena ada anggapan dari sebagian besar mereka bahwa yang mengakat dan menggaji dari pemerintah daerah. Kondisi ini mengakibatkan sulitnya Kementerian Agama kabupaten/Kota untuk melakukan koordinasi para guru PAI. Namun dengan pemberian tunjangan sertifikasi guru PAI di sekolah menjadi kewenangan Kementerian Agama maka pembinaan yang dilakukan oleh Kementerian Agama kepada guru PAI di sekolah dapat berjalan atau dengan kata lain kementerian agama masih memiliki kekuatan di mata mereka.

\section{Mekanisme Pengangkatan dan Penempatan Guru PAI di Sekolah}

\section{Mekanisme Pengangkatan Guru PAI}

Berdasarkan informasi dari Dinas Pendidikan kabupaten/Kota Jumlah guru PAI di SD, SMP, SMA dan SMK di 10 Kabupaten/Kota sudah mencukupi namun berdasarkan informasi dari Ketua

\footnotetext{
${ }^{10}$ Wawancara degan Drs. H. Kadri, Kepala SMP Negeri 4 Lombok Tengah, Tanggal 14 juli 2017

${ }^{11}$ Wawancara dengan Jumaidi, S.Ag., SDN 2 Selong; Drs. Kadri, M.Pd., dan Komang Perasi, SMA N 1 Kota Mataram, Juli 2017.
} 
KKG/MGMP PAI jumlah guru PAI pada satuan pendidikan masih banyak kekurangan. Hal ini diakibatkan oleh tidak meratanya penempatan guru PAI pada sekolah dan banyakanya guru yang pensiun dan meninggal. Dengan kebijakan moratorium menurut Ketua KKG/MGMP maka semakin memperparah kekurangan guru PAI di Kabupaten Lombok Tengah dan Lombok Timur maupun Kota Mataram.

Pengangkatan guru pendidikan agama Islam di Provinsi Nusa Tenggara Barat sebelum moratorium diangkat oleh Departenmen Agama dan Departemen Pendidikan dan Kebudayaan dengan NIP 15 dan 13. Dalam perkembangannya pengangkatan guru PAI di sekolah dilakukan oleh Pemerintah Daerah melalui Dinas pendidikan. Moratorium penerimaan calon pegawai negeri sipil (CPNS) yang masih berlangsung sampai saat ini memiliki dampak atas berkurangnya jumlah guru pendidikan agama Islam. Namun, kebijakan ini, memiliki dampak positif karena para guru harus mengambil 24 jam pelajaran selama sepekan untuk tunjangan profesi. Menyikapi kekurangan guru pendidikan agama Islam, banyak sekolah yang mengangkat guru sendiri untuk memberikan pengajaran agama Islam kepada siswanya. ${ }^{12}$

Pengangkatan guru PAI di sekolah menjadi kewenangan atau otoritas penuh pemerintah daerah melalui Dinas Pendidikan Kabupaten/Kota. ${ }^{13}$ Berdasarkan informasi dari Dinas Pendidikan Kabupaten/Kota Mataram, Kabupaten Lombok Tengah dan Lombok Timur pengankatan guru PAI PNS mengacu pada Undang Undang Pokok Kepegawaian No 43 Tahun 1999. Dalam perkembangannya aparatur sipil negara diatur lebih spesifik dalam UU ASN No 5 Tahun 2014. Para guru tidak tetap (GTT), pegawai tidak tetap (PTT), dan honorer hingga tenaga kontrak yang bekerja di instansi Pemerintah selama minimal tiga tahun akan diangkat langsung menjadi PNS. Dalam pengangkatan guru PAI

${ }^{12} \mathrm{Hj}$. Ika Mursila Wati, SH, MM., Kasi PAI Tingkat Menengah Provinsi Nusa Tenggara Barat, wawancara, 12 Juli 2017

${ }^{13}$ Kasi PAIS Kemenag Kota Mataram, Kabupaten Lombok Tengah dan Kabupaten Lombok Timur. Wawancara, 12 Juli 2017.
PNS dilakukan penyesuaian masa kerja, gaji, penyetaraan ijazah pendidikan terakhir, dan tunjangan yang diperoleh sebelumnya. ${ }^{14}$ Secara bertahap guru PAI honorer akan diangkat oleh pemerintah. Diutamakan pengangkatan guru honorer menjadi guru PNS adalah guru honorer atau guru tidak tetap (GTT) di sekolah negeri yang digaji dari APBN dan APBD. Sampai saat ini, guru honorer di sekolah negeri masih menunggu kepastian pengangkatan guru honorer kategori K2 untuk menjadi guru PNS. Disamping itu juga dilakukan pengangkatan murni melalui tes tertulis bagi mereka yang tidak berstatus guru honorer.

Dalam mengangkat guru PAI honorer SD, SMP, SMA dan SMK sepenuhnya diserahkan kepada sekolah yang bersangkutan berdasarkan kebutuhan jumlah rombel. Mengenai persyaratan, yang terpenting mereka berkualifikasi pendidikan S1 Fakultas Tarbiyah atau jurusan pendidikan agama Islam, memiliki berbagai ketrampilan dibidang keagamaan dan tidak memiliki ikatan kerja di sekolah lain. Pengangkatan guru PAI honorer berdasarkan SK kepala sekolah. Selanjutnya dilaporkan kepada Dinas Pendidikan Kabupaten/Kota. Ada rencana ke depan pengangkatan guru PAI honorer tingkat SMP, SMA dan SMK berdasarkan SK Bupati atau Wali Kota. ${ }^{15}$

\section{Mekanisme \\ Pendistribusian/Penempatan Guru PAI}

Penempatan guru PAI di sekolah menjadi suatu kebutuhan bagi pemerintah daerah Kabupaten/Kota untuk melakukan pemerataan guru PAI di sekolah pada tingkat SD, SMP, SMA dan SMK sesuai dengan jumlah rombel pada masing-masing satuan pendidikan. Penempatan guru PAI SD, SMP, SMA dan SMK di Nusa Tenggara Barat menjadi kewenangan Dinas Pendidikan. ${ }^{16}$

Berdasarkan informasi dari Kepala Seksi PAI Kementerian Agama Kota Mataram, kabupaten Lombok Tengah dan Lombok

${ }^{14}$ M. Taufik, Kasi. PTK PAUD dan PNF Dinas Pendidikan Kota Mataram, wawancara, 12 Juli 2017

${ }^{15}$ Dr. Juju, Sekretaris Dinas Pendidikan Kabupaten Lombok Timur, Wawancara Tanggal, 17 Juli 2017

${ }^{16}$ H. Nasir, Kasi PAKIS Kemenag Kota Mataram, Wawancara Tanggal 12 Juli 2017 
Timur dalam penempatan guru PAI di sekolah, Pihak Dinas pendidikan Kabupaten/Kota tidak berkoordinasi dengan Kementerian Agama Kabupaten/Kota. Kondisi ini mengakibatkan Kementerian Agama sulit untuk mengambil langkah bagi sekolah yang kekurangan guru PAI. Informasi yang diperoleh dari para pengawas PAI masih terdapat beberapa sekolah yang kekurangan guru pendidikan agama Islam. Dalam kaitan ini dalam pemenuhan guru PAI yang dilakukan oleh sekolah harapannya dapat dilaporkan kepada kepada Kementerian Agama Kabupaten/Kota. Namun dalam prakteknya mereka hanya melaporkan kepada Dinas Pendidikan saja.

Penempatan guru PAI di sekolah didasarkan kepada penghitungan kebutuhan operasional sekolah yang dikaitkan dengan kegiatan-kegiatan pembelajaran untuk mencapai standar pelayanan minimal (SPM) dan standar nasional pendidikan (SNP). Disamping itu berdasarkan analisis kesenjangan yang diarahkan pada sekolahsekolah yang kekurangan guru dan sekolahsekolah yang berkelebihan guru.

\section{Kendala Pemenuhan dan Penempatan Guru PAI}

1. Kebijakan moratorium mengakibatkan kurangnya guru PAI di sekolah karena tidak ada pengangkatan guru berstatus PNS, sedangkan guru yang pensiun dalam setiap tahunnya bertambah.

2. Kurang adanya koordinasi antara Dinas Pendidikan dengan Kemenag Kabupaten/ Kota dalam pengadaan dan penempatan guru PAI di SD, SMP, SMA/SMK.

3. Belum meratanya penempatan guru PAI pada sekolah di tingkat Kabupaten/Kota, Kecamatan dan satuan pendidikan.

4. Banyak jumlah guru PAI di sekolah yang pensiun dan meninggal namun belum dilakukan pengangkatan kembali.

5. Dinas Pendidikan tidak Kementerian Agama Kabupaten/Kota dalam pengangkatan dan penempatan guru PAI di sekolah.

\section{Pola Pembinaan Guru PAI}

Pembinaan guru PAI di sekolah dilakukan dengan maksud agar kegiatan yang akan dan sedang dilaksanakan selalu sesuai dengan rencana dan tujuan yang telah direncanakan. Secara lebih luas, pembinaan dapat diartikan sebagai rangkaian upaya pengendalian profesional agar berfungsi sebagaimana mestinya, sehingga rencana untuk mencapai tujuan dapat terlaksana secara efektif dan efisien. Dengan kata lain, pembinaan mempunyai arah untuk mendayagunakan semua sumber daya sesuai dengan rencana dalam rangkaian kegiatan untuk mencapai tujuan yang telah ditetapkan.

Pembinaan guru PAI pada sekolah merupakan tugas dan tanggung jawab Kepala Kantor Kementerian Agama Provinsi melalui Kepala Kantor Kementerian Agama Kabupaten/Kota perlu diselenggarakan secara efektif dan efisien. Untuk itu fungsi pembinaan menjadi sangat penting untuk dilaksanakan baik untuk menghindari atau mencegah penyimpangan pekerjaan atau kekeliruan dalam bekerja, maupun untuk mendapatkan masukan tentang kemungkinan terjadinya kesalahan dalam bekerja, sehingga memungkinkan pimpinan melakukan tindakan pembinaan sedini mungkin, baik pembinaan yang berkaitan dengan pengetahuan maupun pembinaan yang berhubungan dengan mental.

Pembinaan guru PAI di SD, SMP, SMA dan SMK tidak hanya menjadi tanggung jawab Kementerian Agama Provinsi dan Kabupaten/Kota juga oleh pemerintah daerah melalui Dinas Pendidikan dan Kebudayaan. Adapun bentuk kegiatan pembinaan guru PAI yang dilakukan oleh Kementerian Agama dan Dinas Pendidikan dan Kebudayaaan dapat berbentuk Rapat Koordinasi, sosialisasi, Workshop, In House Training, Seminar, lokakarya dan Pembinaan Keprofesionalan Berkelanjutan.

Pembinaan guru PAI di sekolah dilakukan oleh kepala sekolah dan pengawas PAI. Pembinaan ini dilakukan ntuk meningkatkan kinerja guru PAI agar memiliki kesadaran penuh rasa tanggungjawab. Pembinaan ini berhubungan dengan pengetahuan, keterampilan dan pembinaan yang berhubungan dengan sikap.

Pembinaan guru PAI melalui program MGMP PAI baik pada tingkat Pusat, Provinsi, Kabupaten/Kota dan satuan pendidikan ditujukan kepada peningkatan kompetensi guru PAI, peningkatan mutu pembelajaran PAI dan 
pusat informasi kebijakan PAI. Peningkatan kompetensi guru PAI ditujukan pada peningkatan kompetensi guru PAI pada kemampuan pedagogik, kepribadian, profesional dan sosial. Peningkatan mutu pembelajaran PAI meliputi kegiatan pengelolaan intra kurikuler dan ekstra kurikuler. Dan pusat informasi kebijakan PAI akan membantu para guru pendidikan agama Islam untuk memperoleh berbagai informasi yang berkaitan dengan pengembangan pembelajaran pendidikan agama Islam baik dilihat dari materi, teknik mengajar, alat dan media pembelajaran serta pengembangan kurikulum pendidikan agama Islam sesuai kurikulum 2013. Disamping itu sebagai wadah untuk tukar informasi dan saling tukar pengalaman antar guru pendidikan agama Islam dalam rangka mengikuti perkembangan ilmu pengetahuan dan teknologi seperti penggunaan IT dalam pembelajaran.

\section{Pola Pengangkatan Guru PAI}

Pengangkatan guru pendidikan agama Islam di provinsi Nusa Tenggara Barat sebelum moratorium diangkat oleh Departemen Agama dan Departemen Pendidikan dan Kebudayaan dengan NIP 15 dan 13. Dalam perkembangannya pengangkatan guru PAI di sekolah dilakukan oleh Pemerintah Daerah melalui Dinas pendidikan. Semestinya pengangkatan tersebut melalui koordinasi antara Dinas Pendidikan dengan Kementerian Agama baik pada tingklat propinsi maupun Kabupaten/Kota. Secara bersama-sama Kementerian Agama dan Dinas Pendidikan melakukan pemetaan tahu dan mengevaluasi keadaan guru PAI.

Berdasarkan data dan informasi Kepala Bidang PAIS Kementerian Agama Provinsi Nusa Tenggara Barat bahwa jumlah guru PAI yang ada belum seluruhnya mencukupi berdasarkan jenjang pendidikan (SD, SMP, SMA dan SMK). Untuk janjang SD, jumlah guru PAI negeri dan swasta yang ada berjumlah 2.897 orang. Sedangkan hasil penghitungan kebutuhan guru yang merupakan perbandingan antara jumlah rombongan belajar, jumlah jam pelajaran dan jumlah wajib mengajar guru, berjumlah 2.907 orang. Maka pada jenjang SD masih terdapat kekurangan guru PAI sebanyak 10 orang. Selanjutnya pada janjang SMP, jumlah guru PAI negeri dan swasta yang ada berjumlah 725 orang.

Sedangkan hasil penghitungan kebutuhan guru yang merupakan perbandingan antara jumlah rombongan belajar, jumlah jam pelajaran dan jumlah wajib mengajar guru, berjumlah 725 orang. Maka pada jenjang SMP terdapat kelebihan guru PAI sebanyak 6 orang. Pada janjang SMA, jumlah guru PAI negeri dan swasta yang ada berjumlah 342 orang. Sedangkan hasil penghitungan kebutuhan guru yang merupakan perbandingan antara jumlah rombongan belajar, jumlah jam pelajaran dan jumlah wajib mengajar guru, berjumlah 381 orang. Maka pada jenjang SMA masih terdapat kekurangan guru PAI sebanyak 39 orang. Hal ini berbeda pada jenjang SMK terjadi kelebihan 50 orang guru PAI (guru yang ada 233 orang sementara kebutuhannya hanya 183).

Kekurangan jumlah guru PAI di 10 Kabupaten/Kota juga diakibatkan oleh belum meratanya penyebaran guru PAI pada satuan pendidikan oleh Dinas Pendidikan yang tidak berkoordinasi dengan Kementerian Agama Kabupaten/Kota. Kondisi ini mengakibatkan beberapa Kabupaten/Kota masih mengalami kekurangan, sebagai contoh di SMA Negeri 2 Kota Mataram dan SMP Negeri 4 Lombok Tengah berdasarkan jumlah rombongan belajar masing-masing masih kekurangan guru PAI 1 (satu) orang. Hal ini tentunya bisa terjadi pada satuan pendidikan yang lainnya. Pemecahannya, masing-masing sekolah mengangkat guru PAI honorer dengan dibiayai dana BOS. Bila dalam penempatan guru PAI didasarkan pada kebutuhan masing-masing satuan pendidikan maka sekolah yang bersangkutan tidak mengalami kekurangan guru agama Islam.

Kementerian Agama Kabupaten/Kota semestinya dapat bekerja sama dengan Dinas Pendidikan dalam pengadaan guru PAI. Persoalan tersebut tidak hanya dapat diselesaikan oleh Dinas Pendidikan sendiri melainkan melibatkan banyak pihak. Selain itu, juga melibatkan tokoh agama "ulama" untuk mengatasi kekurangan guru PAI. Ini untuk menghindari penanganan masalah oleh orang yang tidak tepat. Disamping itu untuk memenuhi kekurangan guru PAI dapat meminta bantuan ke ormas Islam yang 
memiliki program pendidikan seperti Muhammadiyah dan Ikatan Dai Indonesia (Ikadi).

Solusi sementara yang memungkinkan di antaranya menguatkan, mendukung, dan membimbing kegiatan Rohani Islam (Rohis) di sekolah. Ia melihat banyak pelajar yang memiliki kapasitas keagamaan lebih baik dari teman sebayanya. Satukan dan minta mereka menggerakkan kegiatan rohis sehingga memiliki dampak positif bagi teman-temannya. Pengawasan dan bimbingan sekolah tetap diperlukan. Agar rohis tetap kondusif dan tidak disusupi aliran lain yang tidak sesuai nilai Islam. Kekurangan guru PAI seharusnya tidak terjadi sebab, jumlah lulusan perguruan tinggi Islam cukup banyak jumlahnya. Bila hal yersebut tidak segera diatasi dikuatirkan akan berdampak pada permasalahan akhlak. Sementara itu dapat diasumsikan bahwa peningkatan jumlah guru dan rasio guru-siswa menunjukkan jumlah siswa per rombongan belajar menjadi kecil, dengan demikian proses pembelajaran akan lebih efektif. Ada dua aspek terkait dengan situasi tersebut yang memerlukan eksplorasi lebih lanjut, yakni pengangkatan guru baru dan distribusi guru.

Dalam era desentralisasi, tanggung jawab pengangkatan guru menjadi urusan pemerintah kabupaten/kota dan pemerintah pusat berwenang menetapkan kuota jumlah guru PNS. Kuota untuk guru PNS di semua tingkatan terus meningkat dan menyebabkan terus meningkatnya jumlah guru, terutama di tingkat sekolah dasar. Untuk sebagiannya, peningkatan ini disebabkan oleh perubahan status guru honorer menjadi guru PNS. Logikanya, hal ini akan menyebakan menurunnya jumlah guru non-pns. Namun, kenyataannya di sekolah-sekolah di daerah pedesaan masih banyak ditemukan guru PAI yang berstatus honorer, baik yang dibayar oleh pemerintah daerah, maupun oleh sekolah sendiri. Pelimpahan wenangan pengelolaan guru ke pemerintah daerah belum disertai dengan peningkatan kapasitas untuk pengelolaan guru, khususnya berkaitan dengan analisis kebutuhan nyata di setiap tingkat dan jenis sekolah. Hal ini tercermin dari masih banyaknya daerah yang berkelebihan guru kelas (dilihat dari rasio guru untuk jumlah kelas) di tingkat SD, dan guru mata pelajaran tertentu di tingkat SMP dan SMA jika dilihat dari jumlah rombongan belajar dan beban mengajar guru. Padahal saat ini dapat diasumsikan bahwa jumlah anak usia sekolah dasar terus menurun turun.

Meskipun dalam pengangkatan guru PAI di sekolah dilakukan secara bersama-sama antara Dinas Pendidikan dan Kementerian Agama Kabupaten/Kota tidak berarti tidak ada permasalahan dan apalagi dilakukan secara sepihak oleh Dinas Pendidikan ini akan tetap menimbulkan masalah. Masalahnya, ada anggapan dalam diri guru PAI di angkat dan di gaji oleh pemerintah daerah sehingga mereka kurang menghargai Kementerian Agama. Akibatnya Kementerian agama mengalami kesulitan dalam mengkoordinasikan guru PAI di sekolah. Banyak aspirasi dari berbagai pihak seperti Kepala dan Kasi PAIS di Kementerian kabupaten/kota, Pengawas PAI, Ketua dan anggota KKG/MGMP dan para guru PAI menginginkan pengangkatan guru PAI menjadi kewenangan penuh Kementerian Agama. Hal tersebut cukup beralasan yaitu: 1) memperjelas penanggungjawab penanganan guru PAI di sekolah; 2) memperjelas dasar pengangkatan dan penempatan guru PAI pada tingkat provinsi, kabupaten/kota, kecamatan hingga sampai kepada satuan pendidikan "sekolah"; 3) mempermudah membina guru PAI di sekolah; 4) mempermudah memenuhi kekurangan guru PAI di masing-masing sekolah; 5) mempermudah penyediaan data guru PAI di sekolah secara akurat; 6) menghindari ketersinggungan pengambilan kebijakan oleh dua kelembagaan.

\section{Pola Penempatan Guru PAI}

Berdasarkan informasi Dinas Pendidikan dan Kementerian Agama Kabupaten/Kota tentang penempatan/distribusi guru PAI di sekolah sebagaimana temuan tersebut diatas dapat dikatakan bahwa aparat pemerintah Kabupaten/kota belum memiliki sistem manajemen pengangkatan dan penempatan guru PAI yang efektif. Keberadaan manajemen tersebut menjadi strategis untuk menganalisis secara cermat terhadap kekurangan dan kelebihan guru PAI di setiap satuan pendidikan. Dinas Pendidikan lebih cenderung memberi perhatian kepada pengangkatan guru PAI dibanding penempatannya sehingga 
menimbulkan tidak meratanya penyebaran jumlah guru PAI di masing masing satuan pendidikan. Kondisi ini mengakibatkan ketidaksesuaian antara jumlah guru PAI dengan jumlah rombongan belajar.

Kenyataannya di sekolah-sekolah kabupaten/kota masih banyak guru PAI yang berstatus honorer, baik yang dibayar oleh pemerintah daerah, maupun oleh sekolah sendiri. Pelimpahan wenangan pengelolaan guru PAI ke pemerintah daerah belum disertai dengan peningkatan kapasitas untuk pengelolaan guru, khususnya berkaitan dengan analisis kebutuhan nyata di setiap tingkat dan jenis sekolah. Hal ini tercermin dari masih banyaknya daerah yang berkelebihan guru kelas (dilihat dari rasio guru untuk jumlah kelas) di tingkat SD, dan guru mata pelajaran tertentu di tingkat SMP dan SMA jika dilihat dari jumlah rombongan belajar dan beban mengajar guru. Selama ini masih terjadi berbagai ketimpangan dalam penempatan guru PAI di sekolah. Oleh sebab itu setiap kabupaten/kota dapat melakukan penataan, pemerataan, pendistribusian guru PAI di masing masing sekolah berdasrkan jumlah rombel.

Dengan demikian guru PAI tidak berkumpul di daerah perkotaan, tetapi semua wilayah yang terpencil itu pun dapat dijangkau oleh guru-guru PAI yang berkualitas. Ketidakmerataan guru PAI di sekolah mempunyai dampak negatif pada dua hal. Pertama, pelayanan publik bidang pendidikan agama Islam di sekolah-sekolah yang kekurangan guru PAI menjadi tidak maksimal karena pada jam pelajaran banyak kelas dibiarkan kosong tanpa kegiatan belajar, kriteria ketuntasan mengajar tidak tercapai, dan akhirnya kompetensi murid manjadi rendah. Kedua, guru-guru PAI yang bertugas di sekolah-sekolah yang berkelebihan mengakibatkan guru PAI tidak dapat memenuhi jumlah jam mengajar sesuai standar (24 jam per minggu) karena harus berbagi dengan guru lainnya. Keadaan ini menimbulkan kerugian pada guru PAI yang bersangkutan karena berpengaruh pada pengembangan karir guru, yakni sertifikasi dan kenaikan pangkat yang mensyaratkan terpenuhinya jam mengajar yaitu 24 jam mengajar per minggu.

\section{Pola Pembinaaan Guru PAI}

Dalam Undang-Undang RI No. 20 tahun 2003 tentang Sistem Pendidikan Nasional pasal 66 ditegaskan bahwa pemerintah, pemerintah daerah, dewan pendidikan, dan komite sekolah melakukan pengawasan atas penyelenggaraan pendidikan pada semua jenjang dan jenis pendidikan sesuai dengan kewenangan masing-masing. Berdasarkan Undang-Undang ini maka pemerintah bersama masyarakat secara bersama-sama melakukan pengawasan terhadap penyelenggaraan pendidikan di sekolah termasuk dalam penyelenggaraan pendidikan Agama Islam.

Agar penyelenggraan pendidikan agama Islam berkualitas maka perlu guru yang professional, pembelajaran yang bermutu dan hasil pembelajaran bermuara pada pembentukan karakter peserta didik. Guru PAI merupakan salah satu unsur penting dalam keberhasilan pembelajaran pendidikan agama Islam di sekolah. Untuk itu perlu dilakukan pembinaan kepada guru pendidikan agama Islam di sekolah baik pada tingkat dasar dan menengah untuk meningkatkan kompetensi profesionanya. Pihak-pihak yang terlibat dalam pembinaan guru PAI di sekolah adalah Dinas Pendidikan Kabupaten/Kota dan Kementerian Agama Kabupaten/Kota melalui Kepala Seksi PAIS, Pengawas PAI, KKG/MGMP PAI. Dari sekian unsur KKG/MGMP PAI provinsi dan Kabupaten/Kota memiliki peranan yang strategis dalam meningkatkan kompetensi profesioanal guru pendidikan agama Islam di SD, SMP, SMA dan SMK.

KKG dan MGMP PAI merupakan wadah kegiatan profesional untuk meningkatkan pengetahuan dan kemampuan guru, serta untuk membina hubungan kerjasama secara koordinatif dan fungsional antar sesama guru. Keberadaan KKG dan MGMP memiliki peran penting dalam memajukan dan mengembangkan mutu pendidikan. Karena di dalamnya para guru bertemu, berdiskusi, berkomunikasi, serta mengevaluasi diri dalam rangka meningkatkan kompetensinya baik kompetensi pedagogis, profesional, sosial, dan kepribadian.

Melalui KKG/MGMP meningkatkan professional guru penddikan agama Islam melalui bebrbagi kegiatan yang dilakukan seperti: pertemuan rutin satu bulan sekali, 
menyelenggarakan

penyusunan perangkat pembelajaran, sosialisasi peningkatan kompetensi professional guru PAI, menyelenggarakan kegiatan peringan hari besar Islam, pembuatan program semester dan tahunan, pembuatan soal USBN PAI dan lain-lain. Namun dalam pelaksanaan KKG/MGMP PAI di Nusa Tenggara Barat masih menghadapi berbagai masalah dalam artian masih belum didukung oleh sumber daya manusia dan fasilitas yang memadai. Fasilitas masih menggunakan peralatan yang dimiliki oleh anggota dan sekolah seperti peralatan kantor dan komputer.

Disamping itu masih lemahnya koordinasi dalam kepengurusan KKG/MGMP PAI dan ketidaksiapan pengurus terhadap permasalahan eksternal akan persoalan yang harus dipecahkan dari tiap-tiap guru pendidikan agama Islam di sekolah masingmasing. Persoalan lain masih lemahnya kontrol dan evaluasi pelaksanaan kegiatan KKG/MGMP PAI oleh pihak terkait yaitu pejabat kementerian agama baik pada tingkat pusat, propinsi dan Kabupaten/Kota, pengawas PAI, Kepala sekolah, dan anggota. Selain itu KKG/MGMP masih menghadapi persoalan yaitu: guru pendidikan agama Islam negeri dan swasta belum mampu mengoptimalkan kompetensinya, Guru pendidikan agama Islam belum memanfaatkan organisasi profesi MGMP PAI secara optimal, MGMP PAI belum memiliki sarana prasarana yang memadai masih mengandalkan pinjaman dari milik anggota dan minimnya dana operasional kegiatan MGMP PAI SMA.

Dari berbagai permasalahan tersebut di atas mengakibatkan kurang maksimalnya kinerja KKG dan MGMP yang diakibatkan oleh cara pandang pengurus KKG dan MGMP yang belum terlepas dari sistem birokrasi pemerintah baik pusat maupun daerah, rendahnya akuntabilitas kinerja pengurus, dan belum tersedianya panduan yang operasional pengembangan jaringan kemitraan baik dengan pemerintah maupun swasta. Berdasarkan faktor-faktor tersebut, perlu dilakukan upayaupaya perbaikan, yakni melakukan revitalisasi penyelenggara KKG dan MGMP.

Berbagai masalah ini penting untuk dipecahkan oleh berbagai pihak baik pemerintah daerah melalui Dinas Pendidikan dan Kementerian Agama yang memiliki otoritas utama dalam pembinaan guru PAI di sekolah.

\section{UCAPAN TERIMA KASIH}

Penulis mengucapkan terima kasih kepada Kepala Puslitbang Pendidikan Agama dan Keagamaan Badan Litbang dan Diklat Kementerian Agama yang telah memberikan kesempatan kepada penulis untuk melakukan penelitian Pengadaan dan Pembinaan Guru Pendidikan Agama Islam di Provinsi Nusa Tenggara Barat. Kami juga mengucapkan terima kasih kepada yang terhormat Kepala Bidang Pendidikan Agama Islam Kementerian Agama Provinsi Nusa Tenggara Barat; Ketua KKG/MGMP; Provinsi NTB Kepala Seksi Pendidikan Agama Islam di Kota Mataram, Kabupaten Lombok Tengah dan Kabupaten Lombok Timur, Pengawas dan Guru Pendidikan Agama Islam yang turut membantu memberikan data dan informasi. Semoga tulisan ini bermanfaat untuk pengembangan pendidikan agama Islam ke depan.

\section{PENUTUP}

Berdasarkan analisis data tersebut di atas dapat dirumuskan kesimpuan dan rekomendasi sebagai berikut.

\section{Kesimpulan}

Jumlah guru PAI di Provinsi Nusa Tenggara Barat pada SD, SMP, SMA dan SMK masih mengalami kekurangan sebagai akibat belum meratanya penempatan guru PAI, banyaknya guru PAI yang pensiun adan meninggal serta adanya kebijakan moratorium. Pengangkatan guru PAI di sekolah menjadi kewenangan penuh pemerintah daerah dhi. Dinas Pendidikan Kabupaten/Kota. Kebijakan ini mengakibatkan Kementerian Agama kesulitan dalam melakukan pembinaan kepada guru PAI di sekolah termasuk dalam penempatannya. Kepala Kantor dan Kasi Kementerian Agama Kabupaten/Kota, Pengawas PAI, Ketua dan anggota KKG/MGMP dan guru PAI di sekolah menginginkan pengangkatan guru PAI menjadi kewenangan penuh Kementerian Agama, alasannya: 1) memperjelas penanggungjawab penanganan guru PAI di sekolah; 
memperjelas dasar pengangkatan dan penempatan guru PAI pada tingkat Provinsi, Kabupaten/Kota, Kecamatan hingga satuan pendidikan; 3) mempermudah membina guru PAI di sekolah; 4) mempermudah memenuhi kekurangan guru PAI; 5) mempermudah penyediaan data guru PAI. Penempatan guru PAI yang dilakukan Dinas Pendidikan belum berdasarkan kepada sistem analisis kelebihan dan kekurangan guru PAI berdasarkan satuan pendidikan sesuai jumlah rombongan belajar. Pembinaan guru PAI di sekolah lebih banyak dilakukan oleh Kementerian Agama Kabupaten/Kota dibandingkan Dinas pendidikan melalui berbagai kegiatan KKG/MGMP berupa workshop, seminar, lokakarya dan kegiatan sejenisnya.

\section{Rekomendasi}

Untuk mengatasi kekurangan guru PAI di sekolah dapat dilakukan dengan cara mengangkat guru honorer oleh satuan pendidikan atau melalui Dinas Pendidikan, dengan cara memberikan tugas tambahan mengajar bagi guru PAI yang belum memenuhi jumlah minimal 24 jam untuk mengajar di sekolah lain yang membutuhkan. Pengangkatan, penempatan dan pembinaan guru PAI seharusnya menjadi kewenangan penuh Kementerian Agama. Perlunya system analisis kelebihan dan kekurangan guru PAI di tingkat Dinas Pendidikan, Kementerian Agama Kabupaten/Kota dan Satuan Pendidikan.

\section{DAFTAR PUSTAKA}

Achmad, Sunarto. (2000). Hadits Shahih Bukhari. Jakarta: Setia kawan.

Aminuddin, Kasdi. (2000). Membangun Moral Bangsa. Surabaya: Pustaka Media Utama.

Ahmad, Tafsir. (2004). Ilmu Pendidikan Dalam Perspektif Islam. Bandung: Remaja Rosdakarya.

Ali Hasan, Mukti Ali. (2003). Kapita Selekta Pendidikan Agama Islam. Jakarta: Pedoman Ilmu Jaya.

H. M. Hasbullah. (2015). Kebijakan Pendidikan Dalam Perspektif Teori, Aplikasi, dan Kondisi Obyektif Pendidikan di Indonesia, cet.1 Rajawali Pers, Hal. 165.
Lexi, J. Meleong. (2011). Metodologi Penelitian Kualitatif. Bandung: Remaja Rosdakarya.

Maksum. (2016). Madrasah Sejarah dan Perkembangannya. Jakarta: Logos Wacana Ilmu.

Mulyasa. (2007). Standar Kompetensi dan Sertifikasi Guru. Bandung: Rosdakarya.

Mulyasa. (200)). Kurikulum Berbasis Kompetensi. Bandung: PT. Remaja Rosdakarya.

Oemar, Hamalik. (2006). Pendidikan Guru Berdasarkan Pendekatan Kompetensi. Jakarta: Bumi Aksara.

Pedoman Umum Pengelolaan MAN Model, PPA Consultans in Association with IAIN Walisongo, IAIN.

Rahman, dkk. (2006). Peran Strategis Kapala Sekolah dalam Meningkatkan Mutu Pendidikan. Jatinangor: Alqaprint.

Lisa'diyah, Ma'rifataini. (2014). Edukasi. Jurnal Penelitian Pendidikan Agama dan Keagamaan. 12(1). hal. 75.

Roger Kaufman, Alicia M. Rojas \& Hanna Mayer. (1993). Needs Assessment A User's Guide. Englewood Cliffs, New Jersey; Education Technology Publications.

Samsul Nizar. (2002). Filsafat Pendidikan Islam, Pendekatan Historis, Teoritis, dan Praktis. Jakarta: Ciputat Pers.

Sudirman, A. M. (1994). Interaksi dan Motivasi Belajar Mengajar, Pedoman Guru dan Calon Guru. Jakarta: PT Raja Grafindo Persada.

Syed Sajjad Husain, dkk. (1994). Menyongsong Keruntuhan Pendidikan Islam, diterjemahkan oleh Rahmani Astuti dari judul asli Crisis Muslim Education. Bandung: Gema Risalah Press.

Suyanto, Djihat Hisyam. (2000). Kompetensi Guru. Jakarta: PT Raja Grafindo.

Trianto, Titik Triwulan Tutik. (2007). Sertifikasi Guru dan Upaya Peningkatan Kualifikasi, Kompetensi dan Kesejahteraan. Jakarta: Prestasi Pustaka. Wahjosumidjo. (2002). Kepemimpinan Kepala Sekolah. Jakarta: PT. Raja Grafindo Persada. 